\title{
Substitution of manure source and aerator in nursery media on sandy loam topsoil and their fertility indices 4 months after formulation
}

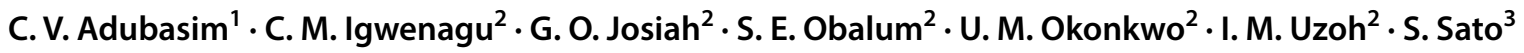

Received: 13 March 2018 / Accepted: 29 August 2018 / Published online: 6 September 2018

(c) The Author(s) 2018

\begin{abstract}
Purpose In soil-based nursery media, topsoil, poultry droppings and sawdust conventionally provide anchorage, nutrients and aeration, respectively. Considering poultry droppings' scarcity and sawdust's inertness nutrient-wise, more readily available organic wastes should be explored as substitutes. Here, we evaluated the effect of such substitution on media fertility, aimed at seeking alternatives to the conventional practice.

Methods In a topsoil-manure-aerator volume ratio of 3:2:1, poultry droppings was substituted with pig slurry (slurry) or cattle dung (dung) as manure and sawdust with rice-husk dust (huskdust) as aerator, giving seven soil-based media including reference medium (topsoil+droppings+sawdust) and the control (topsoil+topsoil+topsoil). They were watered regularly and analysed for fertility parameters 4 months later.

Results Reference had the highest pH (8.60) and topsoil + dung + huskdust/control the lowest (6.83). Substituting sawdust with huskdust enhanced $\mathrm{pH}$, organic matter and $\mathrm{Mg}^{2+}$ in droppings/dung-amended media (topsoil+droppings+huskdust/ topsoil+dung+huskdust) unlike slurry-amended ones where it too reduced total nitrogen $(0.19 \mathrm{vs} 0.11 \%)$. The substitution also enhanced available phosphorus in topsoil+droppings+huskdust $\left(117.50 \mathrm{mg} \mathrm{kg}^{-1}\right)$ and topsoil+dung+huskdust $\left(71.50 \mathrm{mg} \mathrm{kg}^{-1}\right)$ but reduced $\mathrm{K}^{+}$in the latter where it too had moderating effects on $\mathrm{Na}^{+}$. Reference surpassed topsoil+slurry+huskdust for $\mathrm{Ca}^{2+}$, but was surpassed by topsoil+droppings+huskdust for $\mathrm{Mg}^{2+}$. Reference/topsoil+droppings+huskdust and topsoil+slurry+huskdust/control showed highest and lowest CEC, respectively. Excluding pH, topsoil+dung+huskdust and topsoil+slurry+sawdust were, notably, consistently similar. Overall, droppings-amended $>$ dung-amended $>$ slurry-amended media and, for available phosphorus only, sawdust-aerated $<$ huskdust-aerated media.

Conclusion Based on fertility status 4 months after blending, topsoil+droppings+huskdust could serve as alternative to the conventional nursery medium, or topsoil+dung+huskdust where near-neutral $\mathrm{pH}$ is preferred to increased phosphorus/ cations release.
\end{abstract}

Keywords Soil-based media $\cdot$ Organic manure $\cdot$ Pig slurry $\cdot$ Cattle dung $\cdot$ Rice-husk dust $\cdot$ Nutrient release

\section{Introduction}

The formulation of growth media for raising seedlings in the nursery influences the development and quality of the seedlings which in turn greatly defines the success of

S. E. Obalum

sunday.obalum@unn.edu.ng; ijewelle@yahoo.com

1 Department of Plant Biology and Biotechnology, University of Benin, Benin City, Nigeria

2 Department of Soil Science, University of Nigeria, Nsukka 410001, Nigeria

3 Department of Environmental Engineering for Symbiosis, Soka University, 1-236 Tangi-machi, Hachioji-shi, Tokyo 192-8577, Japan their re-establishment and biomass productivity in the field (Bhardwaj 2014). For soil-based media, the materials used to complement the formulation influence their physicochemical properties (Wilson et al. 2001; Sahin et al. 2005), the reason for which the physical and chemical components of such media affect percentage germination, seedling emergence and growth (Ede et al. 2015). When the proportion of silt and clay in a soil-based medium is high, the porosity of the medium may decrease, which implies poor aeration 
and seed respiration (Baiyeri and Mbah 2006). Poor seed respiration results in lowered metabolic energy required for seed germination, thereby leading to seed decay (Baiyeri and Mbah 2006). Therefore, a favourable balance of water and air within the pore system of nursery media is needed to ensure seed survival as well as to support plant growth (Bruckner 1997; Caron and Nkongolo 1999).

Research on nursery media formulation in Nigeria has been traditionally devoted to horticultural concerns, focusing mostly on seedlings performance. Although there have been indications that the physicochemical fertility status of nursery media could influence seedlings performance (Baiyeri and Aba 2013), such status is often not first ascertained empirically before the adoption of media for raising seedlings. A good growing medium should contain the right proportion of materials such that it provides anchorage to seedlings while serving as reservoir of nutrients and water as well as allowing for adequate aeration to particularly ensure the diffusion of oxygen to the roots (Abad et al. 2002; Villagra and Cavagnaro 2006). Sandy loam and/or gravelly topsoils, when used in soil-based nursery media for anchorage, have been found to engender good moisture retention in such media (Ngulube 1996).

In Nigeria, the conventional practice is the use of topsoil mainly to provide anchorage, poultry droppings as manure and river sand as aerator in the volume ratio of 3:2:1 to formulate nursery media for seedlings (Ede et al. 2015; Ngwuta et al. 2016). However, nursery media blended using coarsetextured topsoil and poultry droppings (droppings) benefit from inclusion of sawdust in terms of enhanced total porosity (Baiyeri and Aba 2013). Such inclusion of sawdust thus promotes the aeration of soil-based nursery media. This, coupled with the high density and chemical inertness of river sand, informed the use of sawdust in place of river sand and hence the tagging of topsoil + droppings + sawdust as the reference medium in this fertility-oriented study of soil-based nursery media. In agronomic terms, this topsoil + droppings + sawdust has been shown to be similar to the conventional practice (Nwauzoma and Moses 2013), and to be the best among some soil-based/soilless media without river sand (Alaba et al. 2015). Besides, we are averse to the inclusion of river sand in nursery media, considering the pedo-agronomic implications of the unethical after-use disposal of such media back onto the soil surface.

However, poultry droppings are in high demand for its other uses in agricultural and ecological domains, whereas sawdust contains lignin and is poor nutrient-wise, limiting its role in nursery media to aeration. Amidst these challenges, there is need to explore the use of apparently less nutrient-rich sources of organic manure and more nutrientrich aerator as substitutes. For instance, cattle dung (dung) and pig slurry (slurry) are more available in larger amounts in the agro-industry but are rather poor compared to poultry droppings not in terms of nutrient reserve but mineralization rate (Uzoh et al. 2015). On the other hand, rice-husk dust (huskdust) is generated in large quantities daily, but mostly has low agronomic utility, often times to the detriment of the environment. It is a valuable organic input owing to its small size which allows excellent soil-litter contact as well as its low polyphenol content (Schulz et al. 2003). Besides being of high nutrient content and moisture retention capacity, rice-husk dust is a good aerator (Baiyeri and Mbah 2006).

To our knowledge, virtually no study has evaluated the effect of replacing poultry droppings with pig slurry or cattle dung in soil-based nursery media. Again, despite the potential of rice-husk dust in such media, we are aware of only two studies that evaluated its effect. One is the study by Baiyeri and Mbah (2006) where it was used not necessarily as aerator but to blend soilless media by replacing topsoil in a mixture of topsoil, poultry droppings and river sand in varying ratios. These authors reported enhanced growth of African breadfruit (Treculia Africana) seedlings due to the replacement. In the other study, topsoil + droppings + huskdust and topsoil + droppings + sand were found to outperform topsoil + droppings + sawdust and other soilbased media in terms of seedling performance (Hofeleña and Martinez 2008). Regarding fertility assessment of soil-based media containing poultry droppings or other manures, the use of rice-husk dust to serve both as aerator and for nutrient supply is poorly researched. Use of these organic wastes in blending soil-based nursery media could be a way of beneficially disposing them.

This study was conceptualized out of the present and the future challenge of procuring poultry droppings and the greater availability of the duo of pig slurry and cattle dung as well as the inertness of sawdust vis-à-vis the abundance and great nutrient reserve in rice-husk dust. The study was initiated to investigate, under situations of retaining topsoil in nursery media formulation, the effect of substituting poultry droppings with pig slurry or cattle dung, on one hand, and sawdust with rice-husk dust, on the other, while still maintaining the topsoil-manure-aerator volume ratio of $3: 2: 1$, on their chemical fertility indices. The aim was to seek alternative or even superior formulations to the conventional practice.

\section{Materials and methods}

\section{Location of experiment}

The research was established at the University of Nigeria Teaching and Research Farm in Nsukka campus of the University. The Farm is located at $06^{\circ} 52^{\prime} \mathrm{N}$ and $07^{\circ} 24^{\prime} \mathrm{E}$, and is on an elevation of about $447 \mathrm{~m}$ asl. The mean annual rainfall is $1600 \mathrm{~mm}$, while the mean values for minimum and 
maximum temperatures are 21 and $31^{\circ} \mathrm{C}$, respectively. The area also records variable relative humidity throughout the year in the range of $55-90 \%$.

\section{Media formulation and experimental design}

The experiment involved the formulation of soil-based nursery media from topsoil, three sources of organic manures (poultry droppings, pig slurry and cattle dung) and two aerators (sawdust and rice-husk dust). A small portion of the farm under fallow was identified and cleared, and the needed topsoil collected from the surface layer $(0-20 \mathrm{~cm})$ of the soil. The soil, deeply weathered brownish red coarsetextured (sandy loam) Ultisols, is underlain by false-bedded sandstone. The topsoil was air-dried and homogenised by thorough mixing. Two of the manures, poultry droppings and pig slurry, were procured from the poultry and piggery units, respectively, of the animal section of the farm while the third, cattle dung, was sourced from the local abattoir. All the manures were cured by sun-drying and then crushed and sieved. The sawdust was collected from the 'Timber Shed' at Nsukka and the rice-husk dust from its dumpsite around a rice mill at nearby Adani, both in southeastern Nigeria.

Treatments consist of various combinations of topsoil with each of the three manure sources and each of the two aerators in turn. Because the aim was to contest the conventional formulation, all media had topsoil but poultry droppings was replaced with pig slurry or cattle dung and sawdust with rice-husk dust, maintaining the normal topsoil + manure + aerator ratio of 3:2:1 (vol./vol./vol.). With this substitution pattern, there were six variously formulated nursery media, including the conventional formulation adopted in this study (topsoil-droppings-sawdust), regarded here as the reference medium. A control (topsoil without manure and aerator such that the topsoil + manure + aerator ratio was 6:0:0 on volume basis, translating into topsoil + topsoil + topsoil volume ratio of $3: 2: 1$ ) was also included, bringing the number of treatments to seven. The treatments are summarized in Table 1.

Treatments were thoroughly mixed. Potting was done using 0.15 -L black polyethylene bags with perforations at the bottom for drainage. All treatments were replicated three times in a completely randomised design (CRD) under an 'open' tree shade. Watering of the nursery media was done regularly, the need of which was occasionally obviated or supplemented by rainfall. Sampling was scheduled to take place at 4 months after formulation and potting, when decomposition/mineralization of the various organic materials used in the blending must have attained optimum stage (Schulz et al. 2003; Uzoh et al. 2015). Sub-samples of the soil-based media were taken and air-dried to constant weight. Thereafter, they were crushed and passed through a 2-mm mesh sieve before analyses for some chemical fertility indices.

\section{Laboratory analyses}

Sub-samples of the organic wastes were analysed using standard procedures, to determine their chemical composition shown in Table 2. The $\mathrm{pH}$ of the various media was determined on deionised water and $0.1 \mathrm{~N} \mathrm{KCl}$ suspensions in a 1.0:2.5 soil-liquid ratio (McLean 1982), and the values
Table 1 Summary of the variously formulated soil-based nursery media
Table 2 Chemical composition of the different organic wastes used in the formulation of soilbased nursery media (chemical properties are expressed in percentages)

\begin{tabular}{|c|c|c|c|}
\hline Formulations/treatments (soil-based nursery media) & $\begin{array}{l}\text { Topsoil (three } \\
\text { parts by vol- } \\
\text { ume) }\end{array}$ & $\begin{array}{l}\text { Organic manure } \\
\text { (two parts by } \\
\text { volume) }\end{array}$ & $\begin{array}{l}\text { Aerator (one } \\
\text { part by vol- } \\
\text { ume) }\end{array}$ \\
\hline Topsoil + droppings + sawdust (reference medium) & Topsoil & Poultry droppings & Sawdust \\
\hline Topsoil + droppings + huskdust & Topsoil & Poultry droppings & Rice-husk dust \\
\hline Topsoil + slurry + sawdust & Topsoil & Pig slurry & Sawdust \\
\hline Topsoil + slurry + huskdust & Topsoil & Pig slurry & Rice-husk dust \\
\hline Topsoil + dung + sawdust & Topsoil & Cattle dung & Sawdust \\
\hline Topsoil + dung + huskdust & Topsoil & Cattle dung & Rice-husk dust \\
\hline Topsoil only (control) & Topsoil & Topsoil & Topsoil \\
\hline
\end{tabular}

\begin{tabular}{lllllll}
\hline Organic waste & Organic Carbon & Nitrogen & Phosphorus & Calcium & Magnesium & C:N ratio \\
\hline Poultry droppings & 23.94 & 2.31 & 0.88 & 0.19 & 0.17 & 10.36 \\
Pig slurry & 13.97 & 1.19 & 0.32 & 0.18 & 0.17 & 11.74 \\
Cattle dung & 28.33 & 1.12 & 0.28 & 0.20 & 0.19 & 25.29 \\
Sawdust & 9.11 & 0.30 & 0.36 & 0.29 & 0.12 & 30.37 \\
Rice-husk dust & 37.91 & 0.80 & 0.41 & 2.20 & 1.20 & 47.39 \\
\hline
\end{tabular}


measured potentiometrically using a Beckman's zeromatic glass electrode $\mathrm{pH}$ metre. Organic matter was determined by the Walkley-Black wet dichromate oxidation method (Nelson and Sommers 1996). Total nitrogen was determined using micro-Kjeldahl digestion and distillation procedure as described by Bremner (1996). Available phosphorus was extracted with Bray 2 solution; thereafter, values were measured colorimetrically using the method described by Olsen and Sommers (1982).

To determine the cation exchange properties of the nursery media, the samples were leached with neutral $(\mathrm{pH} 7) 1 \mathrm{~N}$ $\mathrm{NH}_{4} \mathrm{OAc}$. Two of the exchangeable bases $\left(\mathrm{K}^{+}\right.$and $\left.\mathrm{Na}^{+}\right)$in the leachate were measured with flame photometer while the other two $\left(\mathrm{Ca}^{2+}\right.$ and $\left.\mathrm{Mg}^{2+}\right)$ were determined by the complexometric titration method (Thomas 1982). The soil exchangeable acidity was determined by displacement with $1 \mathrm{~N} \mathrm{KCl}$ followed by titration with $\mathrm{NaOH}$ (McLean 1982). Apparent cation exchange capacity (CEC) was determined by the $\mathrm{NH}_{4} \mathrm{OAc}$ displacement method (Rhoades 1982). Thereafter, base saturation of the nursery media was calculated as the ratio of the four exchangeable bases to the effective cation exchange capacity (e-CEC), being the sum of the exchangeable bases and the exchangeable acidity.

\section{Statistical analysis}

One-way analysis of variance for a CRD was done on the data using the software GENSTAT Discovery Edition 1 Release 4.23 (VSN Int. Ltd., Hemel Hempstead, UK). In this analysis, the least significant difference (LSD) was used in mean separation at $p \leq 0.05$.

\section{Results and discussion}

\section{The $\mathrm{pH}$ and organic matter content of the 4-month-old soil-based nursery media}

There were differences in the $\mathrm{pH}$ of the seven nursery media 4 months after formulation (Table 3 ). The values were high, with the highest values of 8.60 recorded for topsoil + droppings + sawdust, the reference medium of this study. This was followed by topsoil + droppings + huskdust and topsoil + dung + sawdust. The lowest $\mathrm{pH}$ values of 6.83 were recorded for both topsoil + dung + huskdust and the control. These two media thus showed $\mathrm{pH}$ values closest to the range of 5.50-6.50 usually considered as optimum for seedlings in nursery media (Goh and Haynes 1977; Miller and Jones 1995). The $\mathrm{pH}$ is an important index of chemical quality and horticultural value of nursery media. For instance, Salifu et al. (2006) reported that $\mathrm{pH}$ alone explained $54 \%$ of variation in height of Quercus rubra seedlings in three variously formulated soilless media. The favourable $\mathrm{pH}$ of the topsoil + dung + huskdust may thus be considered its advantage over the other media formulations.

The presence of rice-husk dust in topsoil + dung + huskdust would partially explain the near-neutral $\mathrm{pH}$ found in this nursery medium (Baiyeri and Mbah 2006). From the present results, it appears that adding cattle dung and rice-husk dust to topsoil to serve as manure and aerator, respectively, in nursery media is ineffectual in increasing the soil $\mathrm{pH}$. Considering that the $\mathrm{pH}$ shown by the control is a 'near-neutral' value usually preferred by seedlings of most plants (Goh and Haynes 1977), it could be that the combination of cattle dung and rice-husk dust has the potential to buffer the $\mathrm{pH}$ of the nursery medium against increases beyond this optimal value. Notably, the replacement of sawdust known to be the conventional aerator with rice-husk dust caused a 'desirable' reduction in the $\mathrm{pH}$ of all media except the ones with pig slurry as organic manure where the opposite prevailed.

All the formulated nursery media showed increases in organic matter content compared with the control; topsoil + slurry + huskdust was the only one where the increase over the control was marginal (Table 3). The highest values were recorded for topsoil + slurry + sawdust and topsoil + dung + huskdust. Therefore, the similarity between topsoil + slurry + huskdust and the control is rather surprising. It could be, however, that pig slurry is more compatible with sawdust and cattle dung with rice-husk dust regarding providing nursery media with aeration that favours certain
Table 3 The $\mathrm{pH}$, organic matter, total nitrogen and available phosphorus contents of the various soil-based nursery media 4 months after formulation

\begin{tabular}{lcclcc}
\hline $\begin{array}{l}\text { Formulations/treatments (soil- } \\
\text { based nursery media) }\end{array}$ & $\mathrm{PH}_{\text {water }}$ & $\mathrm{PH}_{\mathrm{KCl}}$ & $\begin{array}{l}\text { \% Organic } \\
\text { matter }\end{array}$ & \% Total nitrogen & $\begin{array}{c}\text { Available phos- } \\
\text { phorus (mg/kg) }\end{array}$ \\
\hline $\begin{array}{l}\text { Topsoil + droppings + sawdust } \\
\text { (reference medium) }\end{array}$ & 8.60 & 7.57 & 2.80 & 0.17 & 87.70 \\
Topsoil + droppings + huskdust & 8.07 & 7.33 & 3.39 & 0.15 & 117.50 \\
Topsoil+ slurry + sawdust & 7.17 & 6.60 & 4.82 & 0.19 & 57.80 \\
Topsoil + slurry + huskdust & 7.50 & 6.73 & 2.36 & 0.11 & 41.10 \\
Topsoil + dung + sawdust & 8.23 & 7.10 & 3.12 & 0.15 & 37.60 \\
Topsoil+ dung + huskdust & 6.83 & 6.30 & 4.33 & 0.19 & 71.50 \\
Topsoil only (control) & 6.83 & 6.33 & 1.42 & 0.06 & 10.3 \\
LSD $_{0.05}$ & 0.29 & 0.23 & 1.14 & 0.05 & 25.55 \\
\hline
\end{tabular}


biochemical processes that enhance organic matter status in manure-amended soils. In what seems like an inverse of the trend for $\mathrm{pH}$, the replacement of sawdust with rice-husk dust caused organic matter to increase in all those soil-based media amended with poultry droppings (marginally though) and cattle dung; the opposite prevailed in those amended with pig slurry.

\section{Total nitrogen and available phosphorus in the 4-month-old soil-based nursery media}

The results for percent total nitrogen somewhat mirrored those for organic matter content (Table 3). Values were highest in topsoil + slurry + sawdust and topsoil + dung + huskdust and lowest in the control, while the increment in topsoil + slurry + huskdust over the control was marginal. Nursery media content of total nitrogen has, however, been shown not to be a good measure of their fertility status as evaluated by seedling performance; the topsoil + slurry + sawdust and/or topsoil + dung + huskdust would be deemed superior to topsoil + slurry + huskdust showing lower values only if they also show higher contents of other macronutrients including available phosphorus (Asiah et al. 2004). Also, the five nursery media formulations showing similar contents of total nitrogen here may differ when evaluated by seedling performance because both net nitrogen mineralization and net nitrogen immobilization are possible (Clark and Cavigelli 2005). The replacement of sawdust with rice-husk dust caused marginal increases in percent total nitrogen of all media except those amended with pig slurry where the replacement caused a significant reduction instead.

Also, there were differences in available phosphorus content of the various nursery media (Table 3 ). The topsoil + droppings + huskdust recorded the highest values while the control recorded the lowest values. Low levels of other plant nutrients in nursery media from germination through the early weeks of seedling growth could be tolerated because nutrient requirements during this stage are minimal, but not for phosphorus (Miller and Jones 1995). Available phosphorus being highest in topsoil + droppings + huskdust is thus an edge this formulation has over the rest of the nursery media. The trend due to the replacement of sawdust with rice-husk dust (higher values in the nursery media amended with poultry droppings and cattle dung and corresponding lower values in those amended with pig slurry) subsisted; however, the replacement induced marginal reductions this time around.

\section{Cation exchange properties of the 4-month-old soil-based nursery media}

The data for the exchangeable bases and acidity of the various soil-based nursery media 4 months after formulation are shown (Table 4). The content of $\mathrm{K}^{+}$was higher in all the formulated nursery media relative to the control. There were no differences in either of the droppings-amended two media and the slurry-amended two media due to replacement of sawdust with rice-husk dust, but the dung-amended counterparts differed, with topsoil + dung + sawdust showing higher $\mathrm{K}^{+}$than topsoil + dung + huskdust. Perhaps, aerator replacement had no effect on aeration porosity of the droppings-amended and the slurry-amended media (data not yet processed, hence not shown); otherwise, this observation implies that the capacity of the concerned soil-based media to supply potassium is not influenced by their degree of aeration.

The $\mathrm{Ca}^{2+}$, apart from its being higher in the reference medium compared to topsoil + slurry + huskdust, indicated similar values among the seven soil-based media. Hence, the replacements done in the reference medium (i.e, replacing poultry droppings with pig slurry or cattle dung as organic manure and sawdust with rice-husk dust

Table 4 The exchangeable bases and acidity including the cation exchange capacity of the various soil-based nursery media 4 months after formulation

\begin{tabular}{|c|c|c|c|c|c|c|c|c|}
\hline $\begin{array}{l}\text { Formulations/treatments (soil-based } \\
\text { nursery media) }\end{array}$ & $\mathrm{K}^{+}$ & $\mathrm{Ca}^{2+}$ & $\begin{array}{l}\mathrm{Mg}^{2+} \\
\mathrm{cmol}_{\mathrm{c}} \mathrm{kg}^{-1}\end{array}$ & $\mathrm{Na}^{+}$ & $\mathrm{H}^{+}$ & $\mathrm{e}-\mathrm{CEC}$ & $\begin{array}{l}\text { CEC } \\
\mathrm{cmol} \mathrm{kg}^{-1}\end{array}$ & BS \\
\hline $\begin{array}{l}\text { Topsoil }+ \text { droppings }+ \text { sawdust } \\
\text { (Reference medium) }\end{array}$ & 0.32 & 9.33 & 10.00 & 0.19 & 1.00 & 20.85 & 30.53 & 0.95 \\
\hline Topsoil + droppings + huskdust & 0.27 & 6.93 & 12.27 & 0.24 & 0.80 & 20.51 & 24.80 & 0.96 \\
\hline Topsoil + slurry + sawdust & 0.20 & 7.47 & 6.80 & 0.14 & 0.80 & 15.41 & 29.60 & 0.95 \\
\hline Topsoil + slurry + huskdust & 0.25 & 6.00 & 3.40 & 0.23 & 0.80 & 10.68 & 19.47 & 0.93 \\
\hline Topsoil + dung + sawdust & 0.34 & 7.73 & 2.87 & 0.33 & 0.73 & 12.00 & 23.07 & 0.94 \\
\hline Topsoil + dung + huskdust & 0.23 & 7.60 & 6.53 & 0.15 & 0.73 & 15.24 & 34.93 & 0.95 \\
\hline Topsoil only (Control) & 0.04 & 6.80 & 2.67 & 0.03 & 0.67 & 10.21 & 12.67 & 0.93 \\
\hline $\mathrm{LSD}_{0.05}$ & 0.10 & 2.63 & 1.77 & 0.04 & 0.19 & 1.60 & 7.16 & 0.02 \\
\hline
\end{tabular}

$e-C E C$ effective cation exchange capacity, $C E C$ apparent cation exchange capacity, $B S$ base saturation 
as aerator), when considered individually, produced no effect on the $\mathrm{Ca}^{2+}$ content of the soil-based media; differences were due to simultaneous replacement of poultry droppings with pig slurry and sawdust with rice-husk dust.

Treatment also affected $\mathrm{Mg}^{2+}$ of the nursery media with highest and lowest values in topsoil + droppings + huskdust and the control, respectively (Table 4). Contrary to the observation for $\mathrm{pH}$, replacement of sawdust with rice-husk dust caused increases in $\mathrm{Mg}^{2+}$ content of droppings-amended and dung-amended soil-based media but decreases in that of slurry-amended ones. Because of the positive role of $\mathrm{Mg}^{2+}$ in seedling performance in the nursery (Baiyeri and Aba 2013), it can be considered an important fertility index of nursery media. For the droppings-amended media, therefore, the significant improvement in $\mathrm{Mg}^{2+}$ over the reference medium by topsoil + droppings + huskdust may have some agronomic relevance. Notably, topsoil + slurry + huskdust and topsoil + dung + sawdust were so low in $\mathrm{Mg}^{2+}$ that they had similar values as the control, thus pointing to the aforementioned compatibility of pig slurry with sawdust and not rice-husk dust and of cattle dung with rice-husk dust and not sawdust in the formulation of soil-based nursery media.

The $\mathrm{Na}^{+}$content of the nursery media was also affected by treatment. All the formulated media recorded higher values compared with the control. There were also differences among them, with the highest values in topsoil + dung + sawdust, plausibly due to the use of soapy materials for washing in abattoirs. Both the replacement of manure and aerator contributed to these differences. For the aerator replacement, increases in $\mathrm{Na}^{+}$due to the change from sawdust to rice-husk dust were recorded for the droppings- and slurry-amended media; decreases occurred only for the dung-amended media. The decreases were such significant that, among the variously blended media, the highest values in topsoil + dung + sawdust dropped to lowest in topsoil + dung + huskdust. Considering the widely known dispersive tendency of sodium in soils and the fact that it is not an essential but functional plant nutrient (Maathuis 2014), the results just stated favour the adoption of topsoil + dung + huskdust in nursery practice. The topsoil + slurry + sawdust was similar to topsoil + dung + huskdust in $\mathrm{Na}^{+}$content. In the context of doubtful utility of excessive sodium in soils, this observation lends credence to the aforementioned compatibility of pig slurry with sawdust and of cattle dung with rice-husk dust in the formulation of soil-based nursery media.

The exchangeable acidity of the soil-based media was dominated by $\mathrm{H}^{+}$, with $\mathrm{Al}^{3+}$ occurring in traces. Higher values of the $\mathrm{H}^{+}$were recorded in the reference medium relative to the rest of the nursery media. However, the
$\mathrm{H}^{+}$tended to decrease in the order droppings-amended media, slurry-amended media, dung-amended media, and the control.

The aggregated effect of the differences in the exchangeable bases and $\mathrm{H}^{+}$in the e-CEC of the soilbased media shows that all the formulated media but the topsoil + slurry + huskdust were superior to the control. However, all treatments showed e-CEC of above $10 \mathrm{cmol}$ $\mathrm{kg}^{-1}$ regarded as the minimum for nursery media (Miller and Jones 1995). Reference medium and topsoil + droppings + huskdust had similar e-CEC, values of which were higher than the rest of the treatments. By contrast, the replacement of sawdust with rice-husk dust as aerator caused an increase in the e-CEC of both the slurryamended and the dung-amended media. That the change of aerator from sawdust to rice-husk dust affected not the e-CEC of droppings-amended media but that of slurryand dung-amended media suggests that the complementary role of rice-husk dust in enhancing the fertility of nursery media could be masked in the presence of such nutrientrich sources of manure as poultry droppings.

But for the higher values in the reference medium than topsoil+droppings + huskdust, the results for the apparent CEC of the soil-based media were somewhat congruent to those for the e-CEC. Generally, the media formulations of this study were of low cation exchange capacities. This is despite the increases in their organic matter content due to the organic manures involved in the formulation. It could be that the formulations were yet to attain full decomposition and mineralization at the time of sampling which took place 4 months after formulations. Another plausible reason is that texture seems to have stronger influence than organic matter on CEC of the soil used for the formulations (Obalum et al. 2013).

The change of the aerator from sawdust to rice-husk dust resulted in the percent base saturation being higher in droppings- and dung-amended media compared to slurryamended media which together with the control showed the lowest values. Also, neither of the droppings-amended and the dung-amended media differed in percent base saturation due to the change of the aerator from sawdust to rice-husk dust, unlike the slurry-amended media in which the replacement lowered the percent base saturation, hence the lowest values recorded in topsoil + slurry + huskdust.

\section{Conclusions}

Substitution of organic manure and aerator used in complementing coarse-textured topsoil in the blending of nursery media could lead to considerable variations in their chemical fertility indices some 4 months after formulation/blending. 
In the conventional medium (topsoil+ droppings + sawdust), the organic manure poultry droppings could be retained or substituted with cattle dung; this substitution is efficacious only when the aerator sawdust is also substituted with ricehusk dust. Thus, topsoil + droppings + huskdust could serve as an alternative to the conventional medium; however, topsoil + dung + huskdust would be a better one if near-neutral $\mathrm{pH}$ is priced more than phosphorus availability and cation exchange.

The above conclusions are drawn from the preliminary results on fertility status of the variously formulated soilbased nursery media. The study on substitution of manure source and aerator in such media is yet terminated. Presently, we are validating the soil test results via agronomic evaluation of the nursery media commencing from 12 months after formulation, at the end of which the nursery media shall be analysed once again to check for any change in fertility status and to test the observed differences in fertility indices for consistency.

Acknowledgements Special thanks to some students in the B.Agric. Degree Programme of the Faculty of Agriculture of the University of Nigeria Nsukka (UNN) who were in their 4th year in the 2016/2017 Session for their co-operation while initiating and managing the experiment. The support of the staff of the Laboratory Unit of the Department of Soil Science of UNN, particularly Ms Ngozi Ojionuka, in the processing/analyses of the samples is also gratefully acknowledged.

Open Access This article is distributed under the terms of the Creative Commons Attribution 4.0 International License (http://creativeco mmons.org/licenses/by/4.0/), which permits unrestricted use, distribution, and reproduction in any medium, provided you give appropriate credit to the original author(s) and the source, provide a link to the Creative Commons license, and indicate if changes were made.

\section{References}

Abad M, Noguera P, Puchades R, Maquieira A, Noguera V (2002) Physico-chemical and chemical properties of some coconut dusts for use as peat substitute for containerized ornamental plants. Bioresour Technol 82:241-245. https://doi.org/10.1016/S0960 -8524(01)00189-4

Alaba FT, Motolani AO, Adeola AC (2015) Efficiency of seed treatments and different growth media on the germination of seeds of Xylopia aethiopica (Dunal) A. Rich J Biol Chem Res 32:849-853

Asiah A, Mohd Razi I, Mohd Khanif Y, Marziah M, Shaharuddin M et al (2004) Physical and chemical properties of coconut coir dust and oil palm empty fruit bunch and the growth of hybrid heat tolerant cauliflower plant. Pertanika J Trop Agric Sci 27:121-133

Baiyeri KP, Aba SC (2013) Physicochemical characteristics of nursery media formulated from organic wastes influenced growth and dry matter yield of banana (Musa AA var. Pisang lilin) plantlets. Niger J Hort Sci 17:135-145

Baiyeri K, Mbah BN (2006) Effects of soilless and soil-based nursery media on seedling emergence, growth and response to water stress of African breadfruit (Treculia Africana Decne). Afr J Biotechnol 5:1405-1410
Bhardwaj RL (2014) Effect of growing media on seed germination and seedling growth of papaya cv. 'Red Lady'. Afr J Plant Sci 8:178-184. https://doi.org/10.5897/AJPS11.265

Bremner JM (1996) Total nitrogen. In: Sparks DL (ed) Methods of soil analysis part 3: chemical methods, vol 5. Soil Science Society of America, Madison, pp 1085-1122

Bruckner U (1997) Physical properties of different potting media and substrate mixture-especially air- and water-capacity. Acta Hortic 450:263-270. https://doi.org/10.17660/ActaHortic .1997 .450 .31

Caron J, Nkongolo VKN (1999) Aeration in growing media: recent developments. Acta Hort 481:545-551

Clark S, Cavigelli M (2005) Suitability of composts as potting media for production of organic vegetable transplants. Compost Sci Util 13:150-156. https://doi.org/10.1080/1065657X.2005.10702 232

Ede AE, Ndubuaku UM, Baiyeri KP (2015) Media effects on emergence and growth of Moringa (Moringa oleifera Lam) seedlings in the nursery. Am J Exp Agric 7:181-189. https://doi.org/10.9734/ AJEA/2015/13602

Goh KM, Haynes RJ (1977) Evaluation of potting media for commercial nursery production of container-grown plants. N Z J Agric Res 20:363-370. https://doi.org/10.1080/00288233.1977.10427 348

Hofeleña LT, Martinez CP (2008) Factors influencing growth performance of Jatropha curcas L. (Tuba-Tuba) seedlings. Southeast Philipp J Res Dev 16:89-101

Maathuis FJM (2014) Sodium in plants: perception, signalling, and regulation of sodium fluxes. J Exp Bot 65:849-858. https://doi. org/10.1093/jxb/ert326

McLean EO (1982) Soil pH and lime requirement. In: Page AL, Miller RH, Kenney (eds) Methods of soil analysis, part 2: chemical and microbial properties. Agronomy monograph no. 9. American Society of Agronomy, Madison, pp 199-224

Miller JH, Jones N (1995) Organic and compost-based growing media for tree seedling nurseries. World bank technical paper no. 264forestry series. The World Bank, Washington, p 75

Nelson DW, Sommers LE (1996) Total carbon, organic carbon and organic matter. In: Sparks DL (ed) Methods of soil analysis, part 3: chemical and microbial properties. American Society of Agronomy, Madison, pp 539-580

Ngulube MR (1996) Ecology and management of Uapaca kirkiana in Southern Africa. PhD Thesis, University of Wales

Ngwuta AA, Peter-Onoh CA, Obiefuna JC, Chigbundu NI, Nwokeji EM, Chris-Emenyonu CM, Metu CN (2016) Juvenile phenology of Jatropha curcas as influenced by selected nursery growth media. Int J Agric Rural Dev 19:2506-2510

Nwauzoma AB, Moses K (2013) Factors affecting seedling emergence and dry matter characteristics in Musa balbisiana Colla. ISRN Bot 2013:5. https://doi.org/10.1155/2013/582581

Obalum SE, Watanabe Y, Igwe CA, Obi ME, Wakatsuki T (2013) Improving on the prediction of cation exchange capacity for highly weathered and structurally contrasting tropical soils from their fine-earth fractions. Commun Soil Sci Plant Anal 44:1831-1848. https://doi.org/10.1080/00103624.2013.790401

Olsen SR, LE Sommers (1982) Phosphorus. In: Page AL, Miller RH, Keeny (eds) Methods of soil analysis, part 2: chemical properties, 2nd edn. Agronomy monograph no. 9. American Society of Agronomy, Madison, pp 15-72

Rhoades JD (1982) Cation exchange capacity. In: Page AL (ed) Methods of soil analysis, part 2: chemical methods. Agronomy monograph no. 9. American Society of Agronomy, Madison, pp 149-157

Sahin U, Ors S, Ercisli S, Anapali O, Esitken A (2005) Effect of pumice amendment on physical soil properties and strawberry plant growth. J Central Europ Agric 6:361-366 
Salifu KF, Nicodemus MA, Jacobs DF, Davis AS (2006) Evaluating chemical indices of growing media for nursery production of quercus rubra seedlings. HortScience 41:1342-1346

Schulz S, Tian G, Oyewole B, Bako S (2003) Rice mill waste as organic manure on a degraded Alfisol. Agric Ecosyst Environ 100:221230. https://doi.org/10.1016/S0167-8809(03)00198-1

Thomas GW (1982) Exchangeable cations. In: Page AL (ed) Methods of soil analysis, part 2: chemical methods. Agronomy monograph no. 9. American Society of Agronomy, Madison, pp 159-165

Uzoh IM, Obalum SE, Ene J (2015) Mineralization rate constants, halflives and effects of two organic amendments on maize yield and carbon-nitrogen status of loamy Ultisol in southeastern Nigeria. Agro-Sci 14:35-40. https://doi.org/10.4314/as.v14i3.7
Villagra PE, Cavagnaro JB (2006) Water stress effects on the seedling growth of Prosopis argentina and Prosopis alpataco. J Arid Environ 64:390-400. https://doi.org/10.1016/j.jarid env.2005.06.008

Wilson SB, Stoffella PJ, Graetz DA (2001) Use of compost as a media amendment for containerized production of two subtropical perennials. J Environ Hort 19:37-42

Publisher's Note Springer Nature remains neutral with regard to jurisdictional claims in published maps and institutional affiliations. 